\title{
TERAJU
}

Teraju: Jurnal Syariah dan Hukum

Volume 01 Nomor 02, September 2019

DOI: $10.35961 /$ teraju.v1i02.45

\section{Kontribusi Maslahah Al-Thufi dalam Pembaharuan Hukum Islam di Era Kontemporer}

\author{
Zulfa Hudiyani \\ STAIN Sultan Abdurrahman Kepulauan Riau \\ zulfabudiyani11@gmail.com
}

\begin{abstract}
Abstrak
Artikel ini ingin mendongkrak lebih aktif tentang argumen para sarjana hukum Islam yang mengatakan bahwa al-Thufi merupakan seorang ulama yang dipandang 'nyeleneh' dalam menggunakan mashlahah mursalah dalam istinbath hukum. Pemikirannya tentang maslahah dikenal oleh sebagian peneliti hukum Islam sebagai pemikiran yang bias. Karena menurutnya, apabila terjadi pertentangan antara nash yang qath'i dengan kemaslahatan didalam subutut dilalah, maka maslahah harus didahulukan dan menangguhkan nash. Lantas, bagaimana sebenarnya al-Thufi dengan konsep mashlahahnya? Dan Bagaimana aplikasi mashlahah mursalah al-Thufi dan kontribusinya di era kontemporer?. Adapun pendekatan yang digunakan dalam studi ini adalah pendekatan interpretasi dalam rangka memahami pemikiran seorang tokoh melalui karya-karyanya dan pendekatan fenomenologi. Dengan pendekatan library research terhadap literatur-literatur terkait, kajian ini menyimpulkan bahwa kontribusi pemikiran Al-Thufi tentang maslahat sungguh relevan pada era sekarang. Dengan konsepnya yang paling mendasar, yaitu kemaslahatan manusia juga termasuk tujuan syariat Islam.
\end{abstract}

Kata Kunci: Najamuddin Al - Thufi, Maslahah Mursalah, Istinbath Hukum.

\begin{abstract}
This article wants to jack up more actively about the arguments of Islamic law scholars who say that al-Thufi is a scholar who is considered "eccentric" in using mashlahah mursalah in istinbath law. His thoughts about maslahah are known by some Islamic law researchers as bias thinking. Because according to him, if there is a conflict between the texts that are qath'i with the benefit in sub knees, then the issue must take precedence and suspend the texts. So, how exactly is al-Thufi with the concept of mashlahah? And how does the application of mashlahah
\end{abstract}


mursalah al-Thufi and its contribution in the contemporary era?. The approach used in this study is the interpretation approach in order to understand the thoughts of a character through his works and the fenomenological approach. With a library research approach to related literatures, this study concludes that the contribution of Al-Thufi's thoughts about the maslahat is really relevant in the current era. With the most basic concept, namely the benefit of humans is also included in the purpose of Islamic law.

Keywords: Najamuddin Al - Thufi, Maslahah Mursala h, Istinbath of Law

\section{Pendahuluan}

Dalam rangka mewujudkan eksistensi maqasid syariah pada setiap mukallaf, maka setiap perbuatan harus berdasarkan sumber-sumber pokok (almashādir al-ashliyah). ${ }^{1} \quad$ Namun, seiring dengan perubahan dinamika sosial dari masa ke masa yang terus berkembang dengan munculnya berbagai kasus atau peristiwa hukum yang tidak ada jawabannya secara tegas dan khusus dalam sumber pokok tersebut, maka diperlukanlah metode lain dengan menggunakan metode al-far'iyyah, antara lain istihsan, istihab, al-'urf, mazhab alshahabi, dan maslahah al-mursalah. ${ }^{2}$

Maslahat manusia yang menjadi tujuan disyari'atkannya hukum Islam adalah kemaslahatan di dunia dan di akhirat, lahir dan batin. Sebaliknya, keterikatan yang berlebihan pada nash, seperti yang dipromosikan oleh faham ortodoksi, telah membuat prinsip kemaslahatan hanya sebagai jargon kosong, dan Syari'ah yang pada mulanya adalah jalan telah menjadi tujuan bagi dirinya sendiri. ${ }^{3}$ Al-Thufi salah seorang ulama yang terkenal dengan konsep

\footnotetext{
${ }^{1}$ M. Adib Salih, Mashādir Al-Tasyri' AlIslāmi Wa Manāhij Al-Istimbāth, (Dimasyiq: Maktabah At-Ta'awuniyah, 1967), hal 437.

${ }^{2}$ M. Adib Salih, Mashādir Al-Tasyri' AlIslāmi Wa Manāhij Al-Istimbāth, hal 437.

${ }^{3}$ Masdar F. Mas'ud, "Meletakkan Kembali Maslahat sebagai Acuan Syari'ah", dalam Jurnal Ilmu dan Kebudayaan Ulumul Qur'an No.3, Vol.VI tahun 1995, h. 94
}

maslahatnya, bagi kalangan peneliti hukum islam, beliau bergerak sangat progresif dan inovatif, yaitu mempergunakan maslahah mursalah sebagai landasan hukum meskipun harus mendahulukannya dari nash dan ijma' jika terjadi pertentangan dengan nash dan ijma'. Mashlahah mursalah menduduki tempat terkuat dalam berhujjah.

Najamuddin al-Thufi merupakan seorang ulama ushul figh bermazhab Hambali. Dia dikenal dengan konsep maslahah. Pemikirannya tentang maslahah dikenal oleh sebagian peneliti hukum Islam sebagai pemikiran yang bias. Karena menurutnya, apabila terjadi pertentangan antara nash yang qath'i dengan kemaslahatan didalam subutut dilalah, maka maslahah harus didahulukan dan menangguhkan nash karena syari'at diturunkan untuk mewujudkan kemaslahatan manusia. ${ }^{4}$ Selain itu, pemikiran Najamuddin al-Thufi tersebut dianggap oleh sebagian ulama ushul fiqh sebagai pandangan kaum Syi'ah, ${ }^{5}$ dan

${ }^{4}$ Yusuf Qaradhawi, Dirāsah fi Fiqh Maqāshid al-Syarī'ah: Baina al-Maqāshid alKulliyyah wa Nushūs al-Juz'iyyah, (Mesir: Dar Syuruq: 2007), hal, 100-111.

${ }^{5}$ Muhammad Abu Zahrah, Ibnu Hanbal wa Atsāruhu wa Fiqhuhu, (Mesir : Dar al-Fikr alArabi, t.th.), h. 361. Pandangan yang menyebut al-Thufi sebagai penganut aliran Syi'ah tidak sepenuhnya benar karena biasanya para ulama Syi'ah melaksanakan hukum dari ulama Sunni, yaitu dari mazhab Syafiei, sementara al-Thufi penganut mazhab Hambali.Selain itu, tidak ada dalam penjelasan dalam biografi ulama Syi'ah 
dianggap bias untuk diterapkan karena telah mengemukakan kemungkinan terjadinya pertentangan antara nash dengan maslahah. Menurut al-Thufi, pada dasarnya firman Allah SWT dan sabda Rasulullah SAW bertujuan untuk kemaslahatan manusia. Karenanya, keberadaan maslahah sebagai landasan hukum tidak diragukan dan dapat dijadikan dalil mandiri. ${ }^{6}$ Oleh karena itu, Konsep maslahah mursalah versi Al-Thufi disebut juga oleh sebagian akademisi mewakili pandangan yang radikal dan liberal tentang maslahah.

Diskursus seputar permasalahan konsep maslahah versi al-Thufi dikalangan peneliti hukum Islam kontemporer masih sangat menarik dan problematik dalam sebuah kajian. Dalam artikel ini, penulis mencoba mengkaji aplikasi mashlahah mursalah al-Thufi dan kontribusinya di era kontemporer dengan menyebutkan beberapa contohnya yang relevan.

\section{Biografi Najamudin Al-Thufi}

Secara historis, al-Thufi lahir dari latar belakang kemunduran Islam khususnya hukum Islam yang menganut pembaharuan. Sedangkan secara sosiopolitik terjadi fenomena disentegrasi serta fanatisme mazhab yang berlebihan, sehingga tidak jarang suatu mazhab menghujat mazhab lain. Al-Thufi lahir dalam keadaaan masyarakat yang kritis dan tidak menentu setelah jatuhnya Baghdad

tentang al-Thufi sebelum masa al-Khansari. Lihat, P.J. Barman T.H. et. all (ed.) The Ensiklopedia of Islam, Vol. X (Leiden : Brill, 2000), h. 588.

6 Hamzah, "Kemaslahatan menurut Najamuddin Al-Thufi”, Jurnal Al-Daulah, Vol 3, No.1, Juni 2014, hal. 102.

${ }^{7}$ M. Zainal Abidin, Konsep Maslahat atThufi dan Signifikansinya Bagi Dinamisasi Hukum Islam, Syariah; Jurnar Ilmu Hukum VII, no.1 Juni 2007, hal 25. pada pasukan Mongol. ${ }^{8}$ Jatuhnya kota Baghdad disebabkan serangan tentara Mongol ini merupakan tragedi yang sangat memilukan dalam lintasan sejarah umat Islam. Karena secara langsung ataupun tidak langsung merupakan titik awal kemunduran dan kehancuran umat Islam, baik secara politik maupun kehidupan sosial dan ilmu pengetahuan.

Qamaruddin Khan mengemukakan bahwa pada waktu itu terjadi pembakaran karya-karya yang sangat berharga sehingga banyak karya yang tidak bisa diselamatkan. Umat Islam sangat kehilangan dokumentasi ilmu pengetahuan sebagai warisan intelektual generasi sebelumnya. $\quad$ Tragedi ini berdampak negatif bagi dunia Islam, karena di satu sisi kondisi politik pemerintahan tidak kondusif, dan di sisi lain pergulatan pemikiran dan pemahaman hukum Islam mengalami kemandegan dan kemunduran yang cukup lama, yaitu sejak pertengahan abad IV H. hingga akhir abad XIII H. ${ }^{10}$

Fenomena stagnasi hukum islam inilah tampaknya yang banyak memberikan pengaruh pada pemikiran alThufi yang untuk ukuran masanya bahkan sekarang pun terlihat sangat liberal. Salah satu pendapat al-Thufi yang cukup kontroversional adalah konsep mashlahah. Konsep mashlahah yang ditawarkan atthufi berbeda dengan ulama lainnya. Disamping kemunculannya berlawanan dengan arus zamannya.Mashlahah al-Thufi dikenal lebih liberal dibanding asySyatibi. ${ }^{11}$

8 Idaul Hasanah, "Konsep Mashlahah Najudin At-Thufi dan Implementasinya", ejournal MM UMM, Hal. 2.

${ }^{9}$ Qamaruddin Khan, Pemikiran Politik Ibn Taimiyah, Alih Bahasa oleh Anas Mahyudin, (Bandung: Penerbit Pustaka, 1983), h. 37.

${ }^{10}$ Yoseph Schacht, An Introduction to Islamic Law, (London: Oxford at the Clarendom Press, 1971), h. 70-72.

${ }^{11}$ Idaul Hasanah, "Konsep Mashlahah Najamuddin At-thufi dan Implementasinya", ejournal MM UMM, Hal. 4. 
Nama lengkap al-Thufi adalah Abu ar-Rabi' Sulaiman bin 'Abd al-Qawi bin 'Abd al-Karim ibn Sa'id. Dinamai alThufi karena dinisbahkan pada desa Thufa di wilayah Sharshar (sharshar al-sufla), dekat Baghdad, tempat ia dilahirkan. Para biographer berbeda pendapat mengenai tahun kelahirkannya. Al-Hafizh ibn Hajar menetapkan bahwa ia dilahirkan pada tahun 657 H. Ibn Rajab dan Ibn al-'Imad menetapkan al-Thufi lahir pada tahun 670 $\mathrm{H}^{12}$ Sumber lain menyebutkan bahwa alThufi hidup antara tahun 657-716 H./1259-1316 M. ${ }^{13}$

$$
\text { Al-Thufi dalam proses }
$$
pendidikannya dikenal sebagai seorang murid yang pintar, memiliki kecerdasan intelektual yang tinggi, dan daya ingat yang kuat. Ia belajar berbagai disiplin ilmu pada ulama yang terkenal pada masanya. ${ }^{14}$

Qadhi al-Qudhat berkata bahwa al-Thufi senantiasa bekerja, membaca hadits, belajar, mengarang, menghadiri belajar bersama kami padahal dia berjalan dari Qus ke Hijaz. Al-Thufi memiliki banyak karangan, diantaranya Mukhtashar at-Tirmidzi, ringkasan kitab , al - Raudhah fi Ushul Fiqh ' karya asy-Syaikh alMuwaffiq, dan syarahnya juga, syarh alArba'in al-Nawawiyah, Syarh alTibrizi fi Mazhab al-Syafi'I, kitab-kitab Maqamat. Saya melihat dia banyak menulis dari hafalannya. Ash-Shafadi berkata bahwa alThufi adalah seorang ahli fiqh mazhab Hambali, sangat mengetahui masalahmasalah furu'mazhab Hambali, seorang penyair dan sastrawan, seorang yang pandai dan cerdik, memiliki majelis Ushul Figh, dari majelis inilah dia melahirkan banyak karya, dan dia seorang yang sangat

\footnotetext{
${ }^{12}$ Musthafa Zaid, Al-Mashlahāt fi al-Tasyrī' al-Islāmi wa Najm al-Dīn al-Thüfi, (T.tp.: Dar alFikr al-Arabi, tt.), hal 67-68.

${ }^{13}$ Najmuddin al-Thufi, Al-Intishārāt alIslāmiyyah fi 'Ilm Muqāranah al-Adyān, Pentahqiq, Ahmad Hujazi al-Saqi, (Mesir: Mathba'ah Dar al-Bayan, tt.), hal 4.

${ }^{14}$ Musthafa Zaid, Al-Mashlahāt fi al-Tasyrī' al-Islāmi wa Najm al-Dīn al-Thūfi, hal 72-73.
}

berharga dalam ilmu Nahwu, bahasa, sejarah, dan yang lainnya. ${ }^{15}$

Al-Thufi dalam merefleksikan gagasan dan pemikiran-pemikiran hukum Islamnya, lebih menonjol dalam pemahaman metodologi hukum Islam yaitu Ilmu Ushul Figh. Teori mashlahah nya yang menjadikan ia kontroversial dikalangan para pemikir konvensional dan kontemporer. ${ }^{16}$ Menjadikan penilaian tersendiri terhadap kapasitas keilmuan, kapabilitas, intektualitas, dan akuntabilitas pandangan-pandangannya.

\section{Perkembangan Mashlahah}

\section{Definisi Mashlahab}

Secara etimologis, mashlabah kata tunggal dari kata al-mashälih, sama dengan al-shaläh, yaitu mendatangkan kebaikan. ${ }^{17}$ Kata al-mashlahah ini sering juga dipertentangkan dengan almafsadat sebagai lawannya, yang berarti sesuatu yang banyak kebaikan dan manfaatnya sebagai lawan mafsadat, yaitu sesuatu yang banyak mendatangkan kerusakan atau kemudaratan. ${ }^{18}$

\footnotetext{
${ }^{15}$ At-Thufi, at-Ta'yīn Fi Syarhi al-Arba'īn, hal. 9.

${ }^{16}$ Penilaian terhadap pendapat al-Thufi sebagai pendapat yang kontroversial semakin terasa jika dilihat bahwa ia adalah pengikut mazhab imam Hambal. Padahal Ahmad bin Hambal oleh sebagian kalangan seperti Dr. Farouq Abu Zaid diberi predikat sebagai "Imam Kaum Fundamentalis". Hal itu disebabkan karena ia adalah tokoh yang mempropagandakan gerakan kembali kepada sumber-sumber Islam yang pertama secara ketat. Dengan kata lain, mazhab Hambali adalah mazhab yang sangat ketat berpegang kepada nash. Lihat: Farouq Abu Zaid, "Hukum Islam antara Tradisionalis dan Modernis", terjemah oleh H. Husein Muhammad dari asy-syariah al-Islamiyah baina alMuhafizin wa al-Mujahiddin, (Jakarta: P3M, 1986), Hal 36.

${ }^{17}$ Ibn Manzhur al-Afriqi al-Mishri, Lisān al'Arab, Jld. Ke 2, (Bairut: Li al-Thiba'ah wa alNasyr, 1955), h. 517.

${ }^{18} \mathrm{Al}$-Fairuzzabadi, Al-Qāmūs al-Muhìth, (Bairut: Dar al-Fikr, tt.), h. 277.
} 
Secara terminologis pengertian mashlahah banyak didefinisikan oleh para ahli ushul fiqh dengan beragam redaksi, tapi substansinya adalah sama, antar lain: Abu Hamid al-Ghazali mendefinisikan bahwa, mashlabah pada prinsipnya adalah ungkapan untuk meraih kemanfaatan atau menolak kemudaratan. ${ }^{19}$ Definisi Al-Ghazali maksudnya adalah memelihara maksud syara' yaitu agama, jiwa, akal, keturunan, dan harta. Berarti segala hal yang bertujuan untuk memelihara lima perkara tersebut adalah mashlahat. Sebaliknya menyianyiakannya adalah mafsadat. Senada dengan definisi yang dikemukakan oleh AlButhi bahwa mashlahah adalah kemanfaatan yang dimaksudkan oleh Syari' yang Maha bijaksana bagi hambahamba-Nya berupa pemeliharaan agama, jiwa, akal, keturunan, dan harta mereka berdasarkan skala prioritas urutan penyebutan, sedangkan manfaat ialah kelezatan dan media ke arahnya, dan menolak dari penderitaan, atau media ke arahnya. ${ }^{20}$

Sementara Najamuddin al-Thufi mendefinisikan mashlahah sebagai berikut;

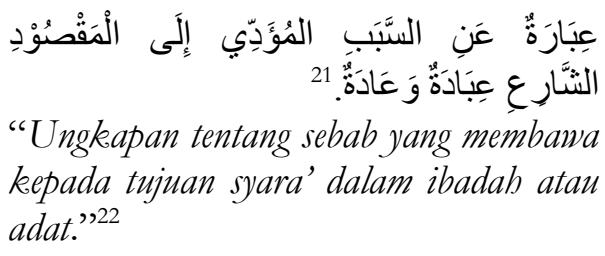

"Ungkapan tentang sebab yang membawa kepada tujuan syara' dalam ibadah atau adat." 22

${ }^{19}$ Abu Hamid al-Gazali, Al-Mustashfa min 'Ilm al-Ushül, (Bairut: Syirkan al-Thiba'ah alFanniyyah al-Muttahidah, 1971), h. 251.

${ }^{20}$ Muhammad Sa'id Ramadhan al-Buthi, Dhawäbith al-Mashlahat fi al-Syarīah alIslämiyyah, (Bairut: Mu'assasah al-Risalah, 1977), h. 23.

${ }^{21}$ Yusuf Hamid al-Alim, al-Maqāshid alĀmmah li al-Syarī'at al-Islāmiyyah, (Kairo: Dar al-Hadits, t.th.),hal. 138.

${ }^{22}$ At-Thufi, al-Ta'yīn Fi Syarhi al-Arba'ìn, (Beirut: Muassasah alRayyan, 1998), hal. 239
Abdul Wahab Khalaf menyebutkan definisi mashlahah mursalah (mashlabah muthlaqah) adalah suatu kemashlahatan dimana syar'i tidak mensyariatkan suatu hukum untuk merealisir kemashlatan itu, dan tidak ada dalil yang menunjukkan diakui atau tidak diakuinya kemashlahatan tersebut. Mashlahah ini disebut muthlaqah karena ia tidak terikat oleh dalil yang menyalahkan atau yang membenarkannya. ${ }^{23}$

Jumhur Ulama berpendapat bahwa mashlahah mursalah adalah hujjah syar'iyyah yang dijadikan dasar pembentukan hukum. Sementara kejadian yang tidak ada hukumnnya dalam nash, ijma', qiyas, atau istihsan ditetapkan hukumnya berdasarkan mashlahah muthlaqah. ${ }^{24}$

Sementara as-Sathibi mengungkapkan bahwa pendapat tentang mashlahah mursalah tidaklah disepakati, tetapi para ahli Ushul Fiqh berbeda pendapat menjadi empat kelompok, yaitu:

a. Al-Qadhi dan sejumlah ahli ushul fiqh menolak mashlahah mursalah, selama tidak disandarkan kepada dalil pokok (al-Qur'an dan hadits).

b. Imam Malik mengakui mashlahah mursalah, dan hukum-hukum dibangun berdasarkan mashlahah mursalah secara mutlak.

c. Imam Syafi'i dan mayoritas mazhab Hanafi berpendapat boleh menggunakan mashlahah mursalah apabila sesuai dengan dalil kully dan juz'iy.

d. Imam al-Ghazali berpendapat bahwa mashlahah mursalah dalam tingkatan tabsin dan tasyin tidak diperbolehkan jika tidak sesuai dengan dalil syara', sedangkan jika

\footnotetext{
${ }^{23}$ Abdul Wahab Khalaf, Ilmu Ushul Fiqh,
} (Kuwait: ad-Dar alKuwaitiyyah, 1968), hal. 84

${ }^{24}$ Abdul Wahab Khalaf, Ilmu Ushul Fiqh, hal. 87 
dalam tingkatan dharuriyyah maka diperbolehkan, tetapi dengan syarat tidak jauh dari ijtihadnya mujtahid yang membawa pada mashlahah. Sementara jika dalam tingkatan hajiyyat, Imam al-Ghazali menolaknya dalam kitab alMushtashfa , dan menerimanya dalam kitab Syifäa al-Ghalìl. ${ }^{25}$

Berdasarkan definisi-difinisi yang telah disebutkan di atas, maka dapat dipahami bahwa mashlahah mursalah merupakan suatu metode ijtihad dalam menggali hukum syara' dengan menggunakan tolak ukur, tujuan syariat Islam diturunkan, bukan berdasarkan dalil nash tertentu.

\section{Dalil Mashlahah Mursalah}

Dalil ulama yang memperbolehkan berhujjah dengan mashlahah mursalah adalah:

a. Kemashlahatan umat manusia selalu baru dan tidak ada habishabisnya. Maka, kalau sekiranya hukum tidak disyariatkan untuk mengantisipasi kemashlahatan umat manusia yang terus bermunculan dan apa yang dituntut oleh perkembangan manusia, serta pembentukan hukum hanya berkisar pada berbagai permasalahan yang diakui oleh syar'i saja, niscaya akan banyak kemashlahatan manusia yang tertinggal oleh zaman dan tempat.

b. Bahwasannya orang yang meneliti pembentukan hukum oleh para sahabat, tabi'in, dan para imam mujtahid maka ia akan merasa jelas bahwasannya mereka telah mensyariatkan berbagai hukum untuk merealisir kemashlahatan ini, bukan karena adanya dalil yang mengakuinya.

${ }^{25}$ At-Thufi, al-Ta'yīn Fi Syarhi al-Arba'īn, hal. 16-17
Al-Qarrafi berkata, "Para sahabat telah mengamalkan berbagai hal karena kemashlahatan secara umum, bukan karena adanya bukti pengakuan yang mendahuluinya." 26

\section{Syarat berbujjah dengan mashlahah mursalab}

Ulama yang berhujjah dengan mashlahah mursalah harus bersikap hati-hati sehingga tidak menjadi pintu bagi pembentukan hukum menurut hawa nafsu dan kesenangan. Oleh karena itu, para ulama mensyaratkan tiga syarat pada mashlahah mursalah yang menjadi dasar pembentukan hukum:

a. Merupakan suatu kemaslahatan yang hakiki, bukan suatu kemaslahatan yang bersifat dugaan. Contohnya mashlahah yang bersifat dugaan adalah pencabutan hak suami untuk mentalaq istrinya dan memberikan hak talak ditangan hakim saja dalam segala situasi dan kondisi.

b. Merupakan kemaslahatan umum, bukan kemaslahatan pribadi. Hukum tidak boleh disyariatkan untuk mewujudkan kemaslahatan khusus bagi penguasa atau pembesar, dan memalingkan pandangan dari mayoritas umat dan kemaslahatan mereka. Namun harus kemaslahatan mayoritas umat manusia.

c. Pembentukkan hukum berdasarkan kemaslahatan tidak boleh bertentangan dengan nash dan ijma'.

Abdul Wahab Khalaf mengatakan dalam bukunya Ilmu Ushul Fiqh, barangsiapa yang mengkhawatirkan permainan, kezaliman, serta mengikuti selera hawa

${ }^{26}$ Abdul Wahab Khalaf, Ilmu Ushul Fiqh, hal. 87 
nafsu dengan mengatasnamakan kemaslahatan umum, maka kekhawatirannya itu dapat ditolak, bahwa kemaslahatan umum tidaklah dijadikan dasar pembentukan hukum, kecuali apabila kemaslahatan itu terdiri dari tiga kriteria diatas. Tidak bertentangan dengan nash syar'i maupun prinsip syar'ie. Ibnu Qayyim berkata: diantara kaum muslimin ada sekelompok orang yang berlebihlebihan dalam memelihara mashlahah mursalah, sehingga mereka menjadikan syariat serba terbatas, yang tidak mampu melaksanakan kemaslahatan hamba yang membutuhkan kepada lainnya. Mereka telah menutup dirinya untuk menempuh berbagai jalan kebenaran dan keadilan. Dan diantara mereka ada pula orang-orang yang melampaui batas, sehingga mereka memperbolehkan sesuatu yang menafikan syariat Allah dan mereka memunculkan kejahatan yang panjang dan kerusakan yang luas. ${ }^{27}$

\section{Pembagian Maslahah}

Imam al-Ghazali membagi mashlahah menjadi tiga bagian: mashlahah mu'tabarah, mashlahah mulghoh, mashlahah mursalah. ${ }^{28}$

Pertama, al-Maslahat alMu'tabarah adalah maslahat yang sesuai dengan al-Qur'an dan Sunnah Rasulullah saw.). Artinya, ada petunjuk dari syāri', baik secara langsung maupun tidak langsung, yang memberikan petunjuk pada adanya maslahat yang menjadi alasan dalam

\footnotetext{
${ }^{27}$ Abdul Wahab Khalaf, Ilmu Ushul Fiqh, (Kuwait: ad-Dar alKuwaitiyyah, 1968), hal. 87

${ }^{28}$ Umar Abd Karim, Dhowabith alushuliyah lil ijtihad fi siyasati syar'iyah, (Libanon: dar Al-K otoob Al-ilmiyah, 1971), hal 80. Lihat juga: AlGhozali, Al-Mustafa, hal 173.
}

menetapkan hukum. Maslahah ini terbagi menjadi dua ${ }^{29}$ :

a. Munasib Mu'atstsir, yaitu petunjuk langsung dari pembuat hukum, artinya ada petunjuk nash atau ijmak yang menetapkan bahwa mashlahah ini dijadikan alasan dalam menetapkan hukum. Contoh, dalil nash yang menunjuk langsung kepada maslahat. Umpamanya tidak baik mendekati perempuan yang sedang haid dengan alasan haid itu adalah penyakit. Hal ini disebut maslahat, karena menjauhkan diri dari kerusakan atau penyakit. Alasan adanya penyakit itu dikaitkan dengan larangan mendekati perempuan yang ditegaskan dalam surah al-Baqarah, ayat 222: "Mereka bertanya kepadamu tentang baidh. Katakanlah: "Haidh itu adalab suatu kotoran". oleh sebab itu hendaklah kamu menjaubkan diri dari wanita di waktu haidh; dan janganlab kamu mendekati mereka, sebelum mereka suci. apabila mereka telab Suci, Maka campurilah mereka itu di tempat yang diperintabkan Allah kepadamu. Sesungguhnya Allah menyukai orang-orang yang bertaubat dan menyukai orang-orang yang mensucikan diri,"

b. Munasib Mualaaim, tidak ada penunjuk langsung oleh syara', baik dalam bentuk nash atau ijma' terhadap maslahah tersebut, namun secara tidak langsung ada. Misalnya, berlanjutnya perwalian ayah terhadap anak gadisnya, dengan alasan anak gadisnya itu belum dewasa. Belum dewasa ini menjadi alasan bagi hukum yang sejenis dengan itu, yaitu perwalian dalam harta milik anak kecil.

Kedua, al-Maslahah al-Mulghah adalah maslahat yang bertentangan

${ }^{29}$ Amir Syarifuddin, Ushul Figh, Jilid II (Cet. I; Jakarta : Logo Wacana Ilmu, 1999), hal.351-353. 
dengan teks wahyu, hadis, atau Ijmak). Hal ini berarti bahwa akal menganggapnya baik dan telah sejalan dengan tujuan syara', namun ternyata syara' menetapkan hukum yang berbeda dengan apa yang dikehendaki oleh maslahat. Bagi Najamuddin alThufi maslahat seperti ini merupakan hujjah terkuat yang secara mandiri dapat dijadikan sebagai sumber hukum (landasan hukum). Konsep ini menjadi sebuah kaidah yang popular yang diakui oleh para ulama 'di mana ada maslahat, di sana terdapat hukum Allah. ${ }^{30}$

Ketiga, al-Maslahah al-Mursalah adalah Maslahat yang secara tegas tidak bertentangan dengan wahyu atau hadis, tetapi juga tidak mendukungnya.

\section{Najamuddin \\ Maslahahnya}

Al-Thufi

dan

Al-Thufi menulis tentang mashlahah dalam kitabnya yang berjudul, Syarh Mukhtashar al-Raudhah dan Kitab al-Ta'yin Fi Syarbi al-Arba'in ketika dia menjelaskan hadits, Lā DharāraWa Lā Dhirāra . ${ }^{31}$

Dalam kitab, Kitab al-Ta'yin FiAsySyarbi al-Arba'in, al-Thufi mengemukakan bahwa al-Qur'an, hadits, Ijma', dan anNadzar, baik secara mujmal maupun tafshil, menunjukkan bahwa Syariat Islam dibangun berdasarkan atas membawa kemaslahatan dan menolak kemadharatan, lalu hal ini dijadikannya sebagai dasar pendapatnya tentang mashlahah. Adapun dalil yang secara mujmal adalah firman Allah swt. QS. Yunus [10]: 57-58: "Hai manusia, Sesunggubnya telah datang kepadamu pelajaran dari Tubanmu dan penyembub bagi penyakit-penyakit (yang berada) dalam dada dan petunjuk serta rabmat bagi orang-orang yang beriman. Katakanlah: Dengan kurnia Allah

\footnotetext{
${ }^{30}$ Muhammad Sa'id Ramadan al-Buti, Dhawabit al-Maslahat $f i$ asSyari'ah alIslamiyah, (Kairo : Dar an- Nahdah al-Arabiyah, 1971), hal. 529

${ }^{31}$ At-Thufi, at-Ta'yin Fi Syarhi al-Arba'in,
} (Beirut: Muassasah alRayyan, 1998), hal. 19 dan rabmat-Nya, bendaklah dengan itu mereka bergembira. Kurnia Allah dan rahmat-Nya itu adalah lebih baik dari apa yang mereka kumpulkan'. Adapun dilalah kedua ayat ini adalah:

1. firman Allah swt.,

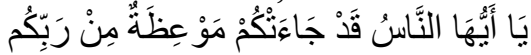

"Hai manusia, sesunggubnya telah datang kepadamu pelajaran dari Tubanmu".

Dalam ayat ini Allah memberikan perhatian untuk memberikan pelajaran kepada manusia. Ini merupakan kemaslahatan manusia yang paling besar. Sebab, dalam pelajaran ini dapat mencegah manusia dari kebinasaan dan menunjukkan mereka kepada hidayah.

2. Al-Qur'an melukiskan bahwa alQur'an merupan penyembuh bagi penyakit-penyakit yang ada dalam dada, seperti keraguraguan dan yang lainnya. Ini merupakan kemaslahatan yang besar.

3. Al-Qur'an melukiskan dirinya sendiri dengan hidayah.

4. Al-Qur'an melukiskan dirinya sendiri dengan rahmat. Dalam rahmat dan hidayah terdapat maslahat.

5. Al-Qur'an menghubungkan hal tersebut pada anugerah dan rahmatNya. Dari anugerah dan rahmat-Nya timbullah kemaslahatan yang besar.

6. Al-Qur'an memerintahkan manusia untuk bahagia, sebagaimana firmanNya, "Dengan kurnia Allab dan rabmatNya, hendaklah dengan itu mereka bergembira." Perintah untuk berbahagia ini bermakna memberikan selamat kepada manusia dengan kebahagiaan. Hal ini karena kemaslahatan yang besar.

7. Firman Allah, "Kurnia Allah dan rahmat - Nya itu adalah lebih baik dari apa yang mereka kumpulkan.'Yang manusia kumpulkan merupakan termasuk kemaslahatan mereka. AlQur'an dan kemanfaatannya lebih maslahat daripada kemaslahatan 
mereka. Yang lebih maslahat daripada maslahat merupakan kemaslahatan yang maksimum.

Tujuh dilalah ayat ini menunjukkan bahwa syariat menjaga dan memperhatikan kemaslahatan mukallaf.

Adapun yang secara tafshil (terperinci) adalah:

1. Al-Qur'an

a. Firman Allah swt.,

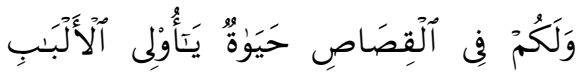

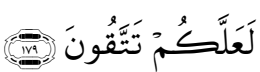

"Dan dalam qishaash itu ada (jaminan kelangsungan) bidup bagimu, Hai orang-orang yang berakal, supaya kamu bertakwa." (QS. Al-Baqarah [2]: 179).

b. Firman Allah swt.,

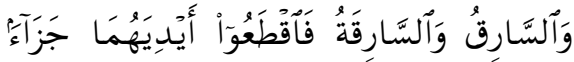

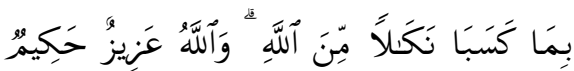

"Laki-laki yang mencuri dan perempuan yang mencuri, potonglah tangan keduanya (sebagai) pembalasan bagi apa yang mereka kerjakan dan sebagai siksaan dari Allah. dan Allah Maha Perkasa lagi Maha Bijaksana." (QS. Al-Maidah [5]: 38).

c. Firman Allah swt

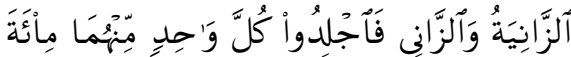

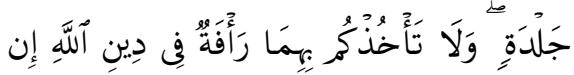

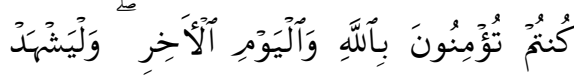

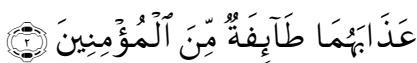

"Perempuan yang berinina dan laki-laki yang berina, Maka deralah tiap-tiap seorang dari keduanya seratus dali dera, dan janganlab belas kasiban kepada keduanya mencegah kamu untuk. (menjalankan) agama Allab, jika kamu beriman kepada Allah, dan hari akbirat, dan hendaklah (pelaksanaan) bukuman mereka disaksikan oleh sekumpulan orang-orang yang beriman." (QS. An-Nur [24]: 2).

Ayat-ayat ini menunjukkan menjaga kemaslahatan, yaitu menjaga kemaslahatan manusia dalam jiwa, harta, dan keturunannya. Dan, masih banyak lagi ayat-ayat yang menunjukkan mashlahah.

2. Hadits

a. Sabda Rasulullah saw.:

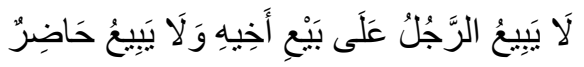

"Janganlah seseorang menjual di atas jualan saudaranya dan janganlah orang yang tinggal di kota menjual barang untuk orang yang tinggal di pelosok,"(HR. Muslim).

b. Sabda Rasulullah saw.:

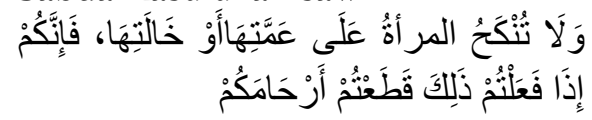

"Tidak boleh seorang wanita dinikabi sebagai madu bagi saudara wanita ayahnya dan tidak pula sebagai madu saudara wanita ibunya. Sebab, sesunggubnya jika kalian melakukan itu, kalian telah memutus memutus bubungan rabim kalian, (HR. AtTirmidzi)."

Dan masih banyak lagi, karena hadits menjelaskan al-Qur'an, sedangkan telah dijelaskan bahwa setiap ayat al-Qur'an mengandung mashlahah, sehingga penjelas mengikuti yang dijelaskan.

3. Ijma'

Para ulama sepakat bahwa alasan hukum dengan mashlahah dan mencegah kerusakan, diantara mereka adalah Imam Malik yang berkata dengan mashlahah mursalah. Bahkan orang yang menentang ijma' sebagai hujjah berpendapat mashlalah dapat dijadikan sebagai dalil.

4. An-Nadzr

Al-Thufi berkata bahwa tidak diragukan lagi menurut orang yang 
memiliki akal yang sehat bahwa Allah menjaga kemaslahatan makhluk-Nya, baik umum maupun khusus. ${ }^{32}$

Paradigma serta konsep berpikir al-Thufi secara spesifik tidak dijelaskan dalam sebuah karya ushul figh, tetapi didalam kitab syarah hadits $A r b$ a' in a $n$ - Nawawiyah, sehingga penulis mengalami kesulitan dalam menjelaskan bagaimana sejatinya konsep pemikiran al-Thufi dalam maslahah mursalah .

Al-Thufi menyakini bahwa dalildalil syari'at itu terdiri dari sembilan belas macam, yaitu : (1). Al- Kitab; (2). AsSunnab; (3). Ijma' al-Ummab; (4). Ijma' abli al-Madinab; (5). Al-Qiyas; (6). Perkataan Sababat Rasul; (7). Mashälib al-Mursalah; (8). Al-Istishab; (9). Al-Baräà ah al-Ashliyab; (10). Al-'awā id; (11). Istigrā; (12). Saddu azZara'i; (13). Istidlal; (14). Al-Istibsan; (15). Al-Abkam bi al-Akhaffi (mengambil yang lebih ringan); (16). Al-Ismah; (17 ). Ijma' ablu alKuffah; (18). Ijma' abl al-'Itrah (keluarga Nabi); (19). Ijma' al-Khulafa' al-Rasyidin. ${ }^{33}$

Menurut al-Thufi, dari seluruh dalil-dalil syara' tersebut, yang paling kuat adalah Nash dan ijma'. Hubungan antara maslahat dan nash berkisar pada tiga hal:

1. Dalil syar'i sejalan dengan maslahat, seperti dalam penetapan had terhadap pelaku pembunuhan, pencurian, qzdzaf, dan yang lainnya.

2. Jika tidak sejalan tetapi memungkinkan dikompromikan melalui takhshish atau taqyid maka keduanya dapat digunakan.

3. Jika antara nash dan mashlahah terjadi benturan dan tidak dapat dikompromikan, maka mashlahah harus didahulukan.

Al-Thufi mengklasifikasikan hukum Islam menjadi dua. Pertama, hukum ibadat dan muqaddarat yang dimaksud dan maknanya tidak dapat hal. 244

${ }^{32}$ At-Thufi, at-Ta'yin Fi Syarhi al-Arba'in,

${ }^{33}$ At-Thufi, at-Ta'yin Fi Syarhi al-Arba'in, (Beirut: Muassasah alRayyan, 1998), hal. 236 dijangkau oleh akal secara detail. Pedoman dalam hukum kelompok pertama ini adalah nash dan ijma'. Kedua, hukum muamalat, adat, siy asah dunyawiyah, dan lainnya yang makna dan maksudnya dapat dijangkau oleh akal manusia. Yang mana landasan dan pedomannya adalah mashlab ahan al-nās (kemaslahatan manusia) baik dikala nash dan ijma' tidak ada. ${ }^{34}$

Dengan demikian, at-Thufi lebih mendahulukan mashlahah mursalah atas nash dan ijmak dalam masalah adat, muamalat, dan lainnya jika nash dan ijmak bertentangan dengan mashlahah mursalah - Namun, tidak dalam masalah ibadah karena itu hak syara', dan tidak diketahui cara menentukan mashlahahnya kecuali dari nash dan ijmak. ${ }^{35}$

Pemikiran al-Thufi mengenai maslahah terdiri dari 4 asas:

Pertama, bahwa akal semata dapat menemukan dan membedakan antara maslahat dan mafsadat

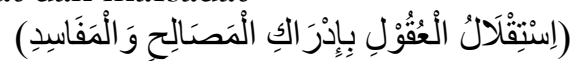

Kedua, maslahat sebagai dalil syara' yang berdiri sendiri tanpa memerlukan nash

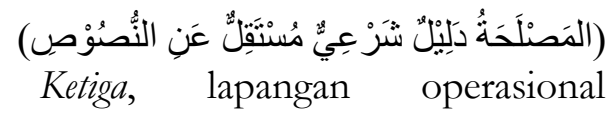
maslahat adalah muamalat dan adat bukan ibadat

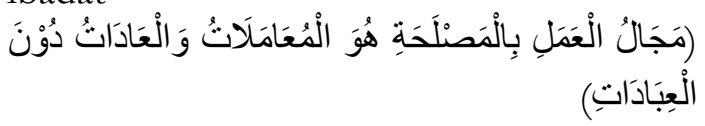

Keempat, maslahat merupakan dalil hukum Islam yang paling kuat

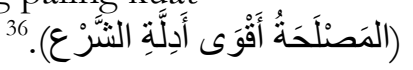

Adapun asas keempat ini merupakan dasar paling penting yang

\footnotetext{
${ }^{34}$ Musthafa Zaid, Al-Mashlahat fi al-Tasyrì' al-Islāmi wa Najm al-Dīn al-Thūfi, hal 235-238. Lihat juga Nur A. Fadlil Lubis" (Medan : Pustaka Widyasarana, 1995), hal. 34-35

${ }^{35}$ At-Thufi, at-Ta'yin Fi Syarhi al-Arba'in, (Beirut: Muassasah al-Rayyan, 1998), hal 241

${ }^{36}$ Lihat: , "Malahah Mursalah menurut AlGhozali dan Relevansinya dengan Pembaharuan Hukum Islam", (disertasi Pascasarjana UIN Jakarta, 1999), hal 112.
} 
melandasi teori al-Thufi tentang maslahah. Baginya, mutlak bahwa mashlahah merupakan dalil syara' yang terkuat. Mashlahah bukan merupakan dalil untuk mengistinbathkan hukum semata ketika tidak terdapat dalam nash dan ijma', melainkan juga harus didahulukan atas nash dan ijma' ketika terjadi pertentangan antara keduanya dengan cara takhshish dan bayan. Namun, yang perlu ditegaskan disini adalah bukan meninggalkan nash semata. Menurutnya, mashlahah bersumber dari sabda nabi:

$$
\text { لَا ضَرَارَ وَلَا ضِرَارَ }
$$

Sabda nabi ini merupakan landasan kokoh untuk mewujudkan dan memelihara kemaslahatan hingga terhindar dari kemafsadatan. Itu sebabnya mengapa kemaslahatan lebih didahulukan. ${ }^{37}$

Argumen-argumen al-Thufi dalam mendahulukan mashlahah dari nash dan ijmak adalah ${ }^{38}$ :

1. Orang-orang yang menolak kehujahan ijma' mengakui kehujahan mashlahah, sebab mashlahah merupakan sesuatu yang tidak diperselisihkan, sedangkan ijma' merupakan sesuatu yang masih diperselisihkan. Oleh karena itu, berpegang pada sesuatu yang disepakati (mashlahah) lebih utama dari pada berpegang pada sesuatu yang diperselisihkan (ijma').

2. Nash-nash sendiri saling bertentangan dan berselisih, sehingga menjadi penyebab perbedaan dalam menetapkan hukum syari'at, sedangkan memelihara mashlahah merupakan sesuatu yang hakiki dan tidak diperselisihkan. Dengan demikian, titik temu hanya ada pada mashlahat dan mengikuti mashlahat lebih baik dari pada menolaknya. Dalam kenyataannya, terjadi kontradiksi antara nash dan mashlahat dalam beberapa hal. Dalam pandangan al-

\footnotetext{
${ }^{37}$ lihat: at-Tufi, Syarh al-Arba'in anNawawiyyah.

${ }^{38}$ Idaul Hasanah, "Konsep Mashlahah Najudin At-thufi dan Implementasinya", ejournal MM UMM, Hal 5.
}

Thufi, telah terjadi pertentangan antara nash dengan mashlahat.

Said Agil Munawwar dalam makalahnya, "Konsep Mashlahah sebagai Salah Satu Sumber Perundangan Islam" mengatakan al-Thufi membedakan antara ajaran yang bersifat teknik dan ajaran yang bersifat tujuan.Ajaran yang bersifat teknik tujuannya adalah untuk melestarikan ajaran agama yang utama.Ajaran yang menjadi landasan untuk menetapkan hukum.Bersifat stabil, misalnya contohcontoh praktis yang diberikan Allah swt. dan Rasul-Nya yang sesuai pada kondisi masyarakat pada waktu itu. Ajaran ini dapat difungsikan selama ia mencapai tujuan. Jika tidak, boleh diubah sesuia keperluan. Kriteria maslahah al-Thufi dan ulama lain memiliki persamaan yaitu samasama menekankan bahwa Al-Mashlahah harus sama-sama berada dalam ruang lingkup tujuan syara'. Tetapi dari sisi lain, menekankan bahwa tidak boleh bertentangan dengan nash tertentu. Namun al-Thufi mengabaikan persyaratan tersebut. ${ }^{39}$

Konsep al-Thufi yang yang sangat menekankan tanggung jawab normal dalam berijtihad dan bersungguh-sungguh dalam menetapkan prinsip al-maslahah, yaitu meninggalkan kesan mempermainkan dalil-dalil syara, maka orang yang ingin menjadikan konsep maslahah sebagai alat untuk melanggar ketentuan syara' demi kemaslahatan. Pentingnya tanggung jawab moral dalam berijtihad dalam pandangan Al-Thufi, maka ia selalu menekankan ini dalam beberapa bagian dalam tulisannya. ${ }^{40}$

Berbicara tentang contoh maslahah al-Thufi, para Ulama mengkritik

\footnotetext{
${ }^{39}$ Said Agil Husin Al Munawar, "Konsep Maslahah sebagai Salah Satu Sumber Perundangan Islam", Jurnal Islamiyyat, Vol 1819, TH. 1998, Hal. 71

${ }^{40}$ Said Agil Husin Al Munawar, "Konsep Maslahah sebagai Salah Satu Sumber Perundangan Islam", Jurnal Islamiyyat, hal 72
} 
bahwa tidak ditemukan contoh maslahahnya.Terutama contoh maslahah yang menggambarkan terjadinya pertentangan dengan ijma'. Kritik para ulama ini, dianalisa oleh sebagian peneliti Hukum Islam, diantaranya Said Agil Husein Munawar yang menjelaskan secara rinci dalam makalahnya. Contoh maslahah al-Thufi ia dapati dalam karyanya Syarh Mukhtashar al-Rawdah. Meskipun contoh itu tidak seektrim dengan konsepnya yaitu pertentangan antara maslahat dengan nash dan ijma'. Seperti ketentuan kafarat bagi orang yang bersetubuh di bulan Ramadhan. Al-Thufi menjelaskan bahwa meskipun jumhur ulama mempersalahkan hasil ijtihad Yahya Ibn Yahya karna beliau berijtihad dengan menentang nash sehingga menurut jumhur ulama hasilnya adalah mashlahah mulghah dalam menetapkan puasa dua bulan berturutturut bagi orang kaya, bukan memerdekakan seorang hamba sebagaimana yang terdapat dalam hadist Arabi. al-Thufi memandang ijtihad Yahya tersebut benar dan sesuai dengan kemaslahatan. Dengan begitu berarti, alThufi telah mengemukakan contoh dari maslahatnya bukan sebagaimana yang dituduhkan oleh para ulama. ${ }^{41}$

Najmuddin al-Tufi dari kalangan Hanabilah telah berlebih-lebihan dalam memandang maslahah. Ia mendahulukan mashlahah dari nash qat'i apabila keduanya bertentangan. Ini benar-benar ra'yu yang ditolak oleh semua mazhab fiqh yang mu'tabar, bukan hanya mazhab Ahmad saja, karena pandangan ini akan membawa pada menyia-nyiakan nash syari'at hanya karena ijtihad berdasarkan akal semata. Seandainya manusia diperbolehkan menerima pandangan ini secara mutlak dalam pensyari'atannya, dan memberi toleransi pada orang-orang peradilan atau para hakim dalam ijtihad

\footnotetext{
${ }^{41}$ Said Agil Husin Al Munawar, Konsep Maslahah sebagai Salah Satu Sumber Perundangan Islam, Jurnal Islamiyyat, hal. 72
}

mereka, sudah dapat dipastikan akan menimbulkan kekacauan yang hebat dalam mengamalkan syari'at dan undangundang. Barangsiapa yang melihat kemaslahatan nash syari'at, maka ia mengamalkan nash tersebut, dan barangsiapa melihat mashlahah yang bertentangan dengan nash syari'at, maka mereka membuang nash, ini adalah puncaknya kekacauan al-Thufi yang telah mengemukan pandangannya ini dan hujjah-hujjahnya ketika menjelaskan hadis Arba'in karya an-Nawawi di bawah hadis: là dharāra wa là dhirār. ${ }^{42}$

\section{Relevansi Maslahah di Era Kontemporer}

Era kontemporer ini banyak sekali problematika yang masuk dalam ranah kajian fikih. Beberapa contoh masalah kontemporer itu akan dijadikan sebagai sample dalam penggunaan mashlah era kontemporer sebagai berikut ini.

1. Larangan menumpuk bahan kebutuhan pokok $^{43}$

Sebuah hadis menyatakan tidak boleh menahan harta kecuali orang aniaya. Hadis ini mengandung larangan menumpuk bahan makanan pokok. Akan tetapi, demi untuk menjaga kestabilan harga dan ketersediaan bahan makanan pokok, seperti beras, gula dan lain-lain, menimbun beras dan semacamnya yang dilakukan oleh Depot Logistik dapat dibenarkan bahkan diharuskan sekalipun bertentangan dengan kandungan hadis tersebut.

2. Penjatuhan Talak ${ }^{44}$

Untuk menjaga keutuhan perkawinan dan orang tidak seenaknya menjatuhkan talak, maka penjatuhan

\footnotetext{
${ }^{42}$ Mustafa Ahmad az-Zarqa', Al-Madkhal, jilid I. hlm. 117-118.

${ }^{43}$ Hamzah, Kemaslahatan menurut Najamuddin Al-Thufi, hal. 101

${ }^{44}$ Hamzah, Kemaslahatan menurut Najamuddin Al-Thufi, hal. 102
} 
talak hanya dianggap sah jika dilakukan di muka sidang pengadilan yang dihadiri oleh dua orang saksi dan dikuatkan oleh keputusan pengadilan.

3. Larangan wanita Menjadi Pemimpin Negara $^{45}$

Hadis Rasulullah saw. melarang seorang wanita menjadi kepala negara. Dalam konteks hadis larangan wanita menjadi kepala negara, karena wanita ketika zaman Rasulullah saw. nasibnya tidak seberuntung wanita saat ini, dulu wanita hanya terisolasi di sekitar lingkungan keluarga, mereka hanya berada dalam tembok-tembok rumah suami atau orang tuanya, mereka tidak memperoleh kesempatan menikmati pendidikan. Pendeknya wanita buta dari urusan kemasyarakatan.Maka wajar Rasulullah menyebutkan bahwa jika suatu kaum menyerahkan urusan kepada wanita maka tunggulah kegagalan atau kehancurannya. Menurut al-Thufi, karena konteksnya sudah sangat berbeda, illat larangannya pun hilang. Oleh karena itu, wanita boleh menjadi kepala negara.

4. Menjual buah-buahan yang masih muda $^{46}$

Dalam Hadis, Rasulullah saw. melarang menjual buah-buahan yang masih muda, yang belum bisa dipastikan akan masak. Maksud hadis ini, ada kekhawatiran bahwa buahbuahan itu rusak sebelum masak yang dapat merugikan pihak pembeli, tetapi kekhawatiran itu bisa dihindari jika teknologi pertanian mampu mewujudkan sistem pemelihraan yang lebih baik sehingga dapat menjamin bahwa itu akan masak dan tidak sampai rusak.

\footnotetext{
${ }^{45}$ Hamzah, Kemaslahatan menurut Najamuddin Al-Thufi, hal. 102

${ }^{46}$ Hamzah, Kemaslahatan menurut Najamuddin Al-Thufi, hal. 102
}

5. Pencatatan Pernikahan

Pencatatan perkawinan ialah salah satu bentuk pembaharuan hukum Islam. Secara formal, tidak terdapat ketentuan nash baik al-Qur an maupun hadis yang memerintahkannya. Akan tetapi, kandungan kemaslahatan didalamnya sangat besar sekali. Sejalan dengan ketentuan syara' mewujudkan kemaslahatan dan mencegah kemudratan atau mafsadat.

\section{Kesimpulan}

Uraian di atas mempertegas sebuah kesimpulan bahwa maslahat sesuatu yang bermanfaat demi kepentingan manusia. Namun harus tetap dalam koridor tujuan syara' dan tidak boleh berdasar keinginan hawa nafsu semata.Untuk meraih manfaat dan menghindari kemudratan. Konsep pemikiran al-Thufi tentang maslahat sungguh relevan pada era sekarang. Dengan konsepnya yang paling mendasar, yaitu kemaslahatan manusia juga termasuk tujuan syariat Islam. Al-Thufi cendrung menempatkan akal lebih tinggi daripada wahyu atau Hadits karena dasar syari'at Islam adalah kemaslahatan, sedangkan maslahat itu sendiri dapat dicapai melalui akal. Oleh karena itu, dalam menentukan suatu maslahah atau mafsadat cukup dengan akal.Karena al-Qur'an dan Sunnah berulangkali mendorong manusia untuk menggunakan akalnya secara maksimal.[]

\section{DAFTAR PUSTAKA}

Al-Munawar, Said Agil. Konsep Maslabah sebagai Salab Satu Sumber Perundangan Islam, Jurnal Islamiyyat. Vol 18-19, TH. 1998.

Al-Alim, Yusuf Hamid. al-Maqāshid alAmmah li al-Syari'at al-Islämiyyah. Kairo: Dar al-Hadits, t.th.

Al-Buthi, Muhammad Sa'id Ramadhan. Dhawäbith al-Mashlahat fi al-Syarìah 
al-Islamiyyah. Bairut: Mu'assasah alRisalah, 1977.

Al-Fairuzzabadi. Al-Qämūs al-Mubith. Bairut: Dar al-Fikr, tt.

Al-Gazali, Abu Hamid. Al-Mustashfa min Ilm al-Ushül. Bairut: Syirkan alThiba'ah al- Fanniyyah alMuttahidah, 1971.

Al-Thufi,Najmuddin. Al-Intishārāt alIslämiyyah fi Ilm Muqāranah al-Adyān, Pentahqiq: Ahmad Hujazi al-Saqi. Mesir: Mathba'ah Dar al-Bayan, tt.

At-Thufi, al-Ta'jin Fi Syarbi al-Arba'in. Beirut: Muassasah alRayyan, 1998.

Hamzah, Kemaslahatan menurut Najamuddin Al-Thufi, Jurnal Al-Daulah, Vol 3, No.1, Juni 2014.

Hasanah,Idaul. Konsep Mashlabah Najudin At-Thufi dan Implementasinya, ejournal MM UMM

Karim, Umar Abd. Dhowabith al-ushuliyah lil ijtihad fi siyasati syar'iyah. Libanon: dar Al-K otoob Al-ilmiyah, 1971.

Khalaf, Abdul Wahab.Ilmu Ushul Figh. Kuwait: ad-Dar alKuwaitiyyah, 1968.

Khan, Qamaruddin.Pemikiran Politik Ibn Taimiyah. Alih Bahasa oleh Anas Mahyudin. Bandung: Penerbit Pustaka, 1983.

Kudrat Abdillah, Maylissabet, M. Taufiq, Kontribusi Bahtsul Masail Pesantren di Madura dalam Menghadapi Perkembangan Hukum Islam Kontemporer, Jurnal Perada: Jurnal Studi Islam Kawasan Melayu, 2019.

Manzhur, Ibn.al-Afriqi al-Mishri, Lisān al'Arab.Jld. 2.Bairut: Li al-Thiba'ah wa al-Nasyr, 1955.

Mas'ud, Masdar F. Meletakkan Kembali Maslahat sebagai Acuan Syari'ab dalam Jurnal Ilmu dan Kebudayaan Ulumul Qur'an No.3, Vol.VI tahun 1995.

P.J. Barman T.H. et. all (ed.) The Ensiklopedia of Islam, Vol. X. Leiden : Brill, 2000.
Qaradhawi,Yusuf. Dirāsah fi Fiqh Maqāshid al- Syarìab: Baina al- Maqāshid alKulliyyah wa Nushūs al-Juг'iyyah. Mesir: Dar Syuruq, 2007.

Salih, M. Adib.Mashādir Al-Tasyri' Al-Islämi Wa Manāhij Al-Istimbāth. Dimasyiq: Maktabah At-Ta'awuniyah,1967.

Schacht,Yoseph. An Introduction to Islamic Law.London: Oxford at the Clarendom Press, 1971.

Syarifuddin,Amir.Ushul Fiqh. Jilid II. Cet. I. Jakarta : Logo Wacana Ilmu, 1999.

Zahrah, Abu Muhammad.Ibnu Hanbal wa Atsārubu wa Fiqhubu. Mesir : Dar alFikr al-Arabi, t.th.

Zaid, Abu Farouq. Hukum Islam antara Tradisionalis dan Modernis. Terj: $\mathrm{H}$. Husein Muhammad dari asy-syariah al-Islamiyah baina alMuhafizin wa al-Mujahiddin. Jakarta: P3M, 1986.

Zaid,Musthafa. Al-Mashlahät fi al-Tasyrì alIslämi wa Najm al-Din al-Thüfi, T.tp.: Dar al-Fikr al-Arabi, tt. 